\title{
POSZTTRAUMÁS STRESSZ ZAVAR ÉS KRÍZISINTERVENCIÓ A HIVATÁSOS TƯZOLTÓ POPULÁCIÓBAN
}

\author{
Szerzők: \\ Sáfrány Judit (Drs.) \\ Eszterházy Károly Katolikus Egyetem
}

Szerző e-mail címe:

safrany12@gmail.com

\author{
Lektorok: \\ Mező Ferenc $(\mathrm{PhD})$ \\ Eszterházy Károly Katolikus Egyetem \\ Kelemen Lajos (PhD) \\ Okoskocka Kft. \\ ...és további két anonim lektor
}

\begin{abstract}
Absztrakt
Jelen tanulmány célja a hivatásos tűzoltó populációban tapasztalt stressz következményeinek, elsősorban a poszttraumás stressz zavar (PTSD) prevalenciája, illetve a tünetegyüttes bemutatása. A nemzetközi szakirodalom áttekintésével a PTSD potenciális rizikó és protektív faktorainak feltárása, valamint a prevenció és krízisintervenció lehetőségeinek felvázolása történik.
\end{abstract}

Kulcsszavak: PTSD, stressz, túzoltó, rizikó és protektív faktorok, prevenció, krízisintervenció

Diszciplina: pszichológia

\begin{abstract}
POSTTRAUMATIC STRESS DISORDER AND CRISIS INTERVENTION

IN THE PROFESSIONAL FIREFIGHTER POPULATION

Recent study aimed to present the consequences and the prevalence of the experienced stress, particularly the posttraumatic stress disorder (PTSD) in the professional firefighter population. The symptoms of PTSD are also listed. The review of the international literature enables the reveal of the risk and protective factors of PTSD, and the methods of prevention and crisis intervention.
\end{abstract}

Keywords: PTSD, stress, firefighter, risk and protective factors, prevention, crisis intervention

Disciplines: psychology

Sáfrány Judit (2021): Poszttraumás stressz zavar és krízisintervenció a hivatásos tűzoltó populációban. Lélektan és hadviselés - interdiszciplináris folyóirat, III. évf. 2021/1. szám. 37-50. doi: 10.35404/LH.2021.1.37 
Ahogyan az ököritófülpösi címerben száz év után is megmaradt az égô csûr szimbóluma, úgy égett bele a falu emlékezetébe is az 1910. március 27-én történt tüzeset. A mai falu elődközsége Szatmárököritó 650 fő részvételével táncmulatságot rendezett egy csűrben, ami egy szerencsétlen fordulat folytán tragédiába torkollott. Azóta is a világ egyik legtöbb áldozattal járó tűzvészei között tartják számon az esetet, mivel 312 ember lelte halálát a mindössze 20 percig tartó tűzben. A következő órákban a falu lakói, a mentésben résztvevők és a túlélők pszichésen erősen zavarodott állapotba kerültek. Az indulatok megfékezésére még a katonaság együttműködésének kérése is felmerült, végül a csendőrök beavatkozása rendezte a helyzetet. A helyszínen az orvosi segítségnyújtás is megkezdődött (Sinkovics, 2010).

A túlélők beszámolója alapján olyan abnormális, a hétköznapi élettel össze nem egyeztethetô esemény résztvevői voltak az emberek, ami mind fizikálisan, mind pszichésen erôs megterhelést jelent. Ezek az élmények azonban nem idegenek a katasztrófáknál, káreseteknél beavatkozó rendvédelmi állomány számára. A hosszú szolgálati idő alatt tapasztaltak szinte beleégnek a szakemberek lelkébe, és hosszabb-rövidebb ideig komoly pszichés nyomást jelenthetnek a mindennapi életbe visszatérve is.

A tűzeseteknél, mûszaki mentéseknél és egyéb tűzoltói beavatkozást igénylő káreseményeknél olyan vizuális, akusztikus, olfaktorikus és egyéb ingerekkel szembesülnek mind az áldozatok, szemtanúk, mind a hivatásukat gyakorló szakemberek, amelyek mindennapi életünk során ismeretlenek. Ezek az abszurd élmények gyakran kimerítik a trauma fogal- mát. Egy átlagember nagy valószínűséggel élete során sosem, esetleg elenyésző alkalommal résztvevője ilyen traumatikus eseménynek. A tűzoltók azonban azokban a szituációkban, helyszíneken kell, hogy helyt álljanak, ahonnan a civilek életüket féltve menekülnek.

Nem szabad azonban figyelmen kívül hagynunk, hogy a tűzoltó is ember, aki saját élettörténettel, akár kritikus élethelyzettel rendelkezik, illetve a mindennapi élet stresszfaktorai őt is érintik. „A falak ereje nem a kövekben van, hanem a védők lelkében." - hangzik el Gárdonyi Géza gondolata Dobó István várkapitány tolmácsolásában. Az Egri csillagok című regényben az író erôs pszichológiai érzékkel rámutat, hogy egy vár védelmében összeadódó erőforrások nemcsak a fizikai ellenállásból, hanem a pszichés jelenlétből is adódnak. Nagyon fontos ezért, hogy napjainkban is kellő hangsúlyt helyezzünk a védekezésben résztvevők mentális jóllétének ápolására, megőrzésére is.

Magyarországon a hivatásos rendvédelmi szervek állományának minden tagja alapellátó orvos és pszichológus ellátási körébe tartozik, akiknek munkáját megfelelően képzett aszszisztencia segíti. Ezáltal lehetőség van arra, hogy szükség szerint adekvát egészségügyipszichológiai prevenció, illetve intervenció történjen, akár az érintett dolgozó saját kérésére, akár elöljárója jelzését követően, valamint a rendszeres szűrővizsgálatok is ezt a célt szolgálják. Annak ellenére, hogy szigorúan beszabályozott elvárásrendszer alapján történik az alkalmassági elbírálás, mégis hangsúlyozandó, hogy ezen intézkedések az állománytagok hosszú távú fizikális és mentális egészségmegőrzését szolgálják. Mivel a jelenlegi törvényi szabályozás értelmében egy hiva- 
tásos szolgálatot teljesítő személy a korábbi gyakorlathoz képest magasabb életkorig marad aktív, különösen fontos a preventív és időben történő interventív ellátás.

Jelen tanulmány a hivatásos tűzoltók populációjában tekinti át az ismétlődő stresszoroknak való kitettség következményeit a pszichés egészség szempontjából, elsősorban a poszttraumás stressz zavar kialakulásának folyamatát, a megoldási lehetőségeket.

\section{Poszttraumás stressz zavar}

A stressz rövid távon való megtapasztalása előnyösen, facilitáló jelleggel (eustressz) hathat a teljesítményre, hiszen élettani hatása teljesítménynövelő hatással bír kognitív és affektív képességeinkre. A tartós stresszállapot azonban már teljesítményredukcióhoz vezethet, debilizáló hatást fejt ki az érintett mûködésére, aki ezáltal nem tud valós képességeihez illeszkedően beavatkozni a mûveletnél, és megnövekszik annak veszélye, hogy további sérülések, károk következzenek be a kárhelyszínen (Mészáros, 2019).

A tömegkatasztrófák egyes fázisai alatt a mentést végzők a túlélőkhöz, szemtanúkhoz hasonló magatartásformákat produkálhatnak. A katasztrófák lefolyásának első szakasza az eseményt megelőző időszak, amikor a felkészülés az elsődleges feladat. Ezt követően az első 48 óra a megküzdés, beszűkülés vagy lemondás reakcióit tartogathatja. Az első hét nap segítségnyújtása során a rugalmasság, illetve a kifáradás jelenhet meg, majd a rendeződés (1-4 hét) a gyász, a betolakodó emlékek, a verbális kifejezés ideje. Végül a visszarendeződés (2 hét-2 év) a különböző pszichés zavarok, maladaptív működésmódok veszé- lyét foglalja magába. Gyakoriak ebben az időszakban a fóbiák, az elkerülő magatartás, a depresszió, a poszttraumás stressz zavar, illetve az alkalmazkodási zavarok (NIH Workshop, 2002).

$\mathrm{Az}$ általános stresszfolyamat traumatikus helyzetekben bármely - alapjában véve egészséges - egyénnél előfordulhat. A fizikális tünetek manifesztálódhatnak fáradtság, szapora légzés és emelkedett pulzusszám, megemelkedett vérnyomás, tremor, fokozott verejtékezés, hányinger-hányás, alvászavar, esetleg rémálmok formájában. Kognitív szinten koncentrációs nehézségek, a tudati működés megváltozása (például zavartság), a gondolati folyamat fellazulása, memóriaproblémák, meglassult tempójú pszichomotorium, döntési krízis, bűntudatérzés, szuicid gondolatok léphetnek fel. Az affektív tényezők involválják a félelmi reakciók, a szorongás, indulatok, irritáltság, deprimált hangulat, tompultság, magányosság és reménytelenség érzéseit (Kovács, 2019).

A traumatikus események ismétlődő átélése a hivatásos tűzoltók körében is megnöveli a kockázatát a poszttraumatikus stressz zavar (PTSD) kialakulásának (Kim és tsai., 2018). A kórkép kritériumait a DSM-5 (2013) és a BNO-10 (2004) diagnosztikai zsebkönyvek tartalmazzák. A DSM-5 a legújabb tudományos eredmények alapján korrekciókat tartalmaz, melynek következtében többek között a PTSD új fejezetbe került: „Traumával és stresszorral összefüggő zavarok”.

A kiváltó ingerek közül a halál vagy a halállal kapcsolatos fenyegetettség, súlyos sérülés vagy szexuális abúzus szerepelhet, mely akár saját átélés, akár mások megfigyelése, illetve közeli személyt érintő hír formájában történhet. A 
kritériumok közül az eseménnyel összefüggő averzív részletek abnormis vagy repetitív jellegú átélése a beavatkozó professzionális alakulatok szempontjából jelent gyakori érintettséget. A traumának való kitettséget követő 3 nap és 4 hét közötti időszakban fellépő tünetek az ,akut stressz zavar” (BNO F43.0) diagnózist valószínúsíthetik a klasszifikációs rendszer alapján. A traumatikus eseménnyel kapcsolatos tünetkategóriákon belül kilenc megléte szükséges a diagnózishoz, ez azonban bármely lehet. Az öt kategória a következő: betolakodó tünetek, negatív hangulat, disszociáció, elkerülés, valamint éberséggel és állandó készenléttel kapcsolatos tünetek. A pontos tüneteket az 1. táblázat tartalmazza.

Amennyiben a zavar tünetei egy hónapon túl is fennállnak, a PTSD kialakulása valószínűsíthetô. Az idői kritérium figyelembe vételénél beszélhetünk akut, késleltetett vagy krónikus állapotról. Az egy-három hónap közötti fennállás akut megnyilvánulásnak tekinthető, míg a traumát követő hatodik hónap után induló zavar késleltetett PTSD. Krónikus fennállásról a három hónapon túl is perzisztáló tünetegyüttes esetében beszélhetünk (Perczel Forintos, 2016).

Az akut stressz zavar fentebb említett tünetein túl a PTSD kialakulásánál előfordulhatnak eltúlzó negatív hiedelmek vagy elvárások (önmagára, másokra vagy a világra vonatkozóan). Kognitív torzítások jelenhetnek meg a trauma okaival vagy következményeivel összefüggésben, melynek eredményeként az érintett önmagát vagy másokat teszi felelőssé.

A tartósan fennálló negatív érzelmek szintén minőségi romlást okoznak az életvezetésben. Redukált érdeklődés és részvétel a jelentősebb aktivitási területeken, valamint interperszonális elidegenedés vagy közöny szintén a tünetegyüttes része.

1. táblázat: Az akut stressz zavar diagnosztikus tünetei (DSM-5, 2013)

\begin{tabular}{|c|c|c|c|c|c|}
\hline $\begin{array}{l}\text { Betolakodó } \\
\text { tünetek }\end{array}$ & \multicolumn{2}{|c|}{$\begin{array}{l}\text { Repetitív, akaratlan, } \\
\text { nyomasztó emlékek. }\end{array}$} & $\begin{array}{l}\text { Visszatérő } \\
\text { rémálmok. }\end{array}$ & $\begin{array}{l}\text { Az események } \\
\text { újraélése (pl. } \\
\text { flashbackek). }\end{array}$ & $\begin{array}{c}\text { Szenvedés a } \\
\text { kulcsingereknek } \\
\text { való expozíció } \\
\text { esetén. }\end{array}$ \\
\hline $\begin{array}{l}\text { Negatív } \\
\text { hangulat }\end{array}$ & \multicolumn{5}{|c|}{ Pozitív érzelmek átélésének tartós nehézsége. } \\
\hline $\begin{array}{l}\text { Disszociatív } \\
\text { tünetek }\end{array}$ & \multirow{2}{*}{\multicolumn{3}{|c|}{$\begin{array}{c}\text { Mind környezete, mind önmaga } \\
\text { valószerúségének módosult átélése. } \\
\text { A nyomasztó emóciók, kogníciók és emlékek } \\
\text { elkerülése. }\end{array}$}} & \multirow{2}{*}{\multicolumn{2}{|c|}{$\begin{array}{l}\text { Amnézia a traumatikus esemény } \\
\text { jelentősebb aspektusaira. } \\
\text { Külső emlékeztetők kerülése (pl. } \\
\text { személyek, helyszínek, témák, } \\
\text { tevékenységek, tárgyak, } \\
\text { szituációk). }\end{array}$}} \\
\hline $\begin{array}{l}\text { Elkerülési } \\
\text { tünetek }\end{array}$ & & & & & \\
\hline $\begin{array}{l}\text { Éberséggel } \\
\text { és állandó } \\
\text { készenléttel } \\
\text { kapcsolatos } \\
\text { tünetek } \\
\end{array}$ & Alvászavar. & $\begin{array}{l}\text { Ingerlékeny } \\
\text { viselkedés } \\
\text { vagy } \\
\text { dühkitörések. }\end{array}$ & Hipervigilancia. & $\begin{array}{l}\text { Koncentrációs } \\
\text { problémák. }\end{array}$ & $\begin{array}{l}\text { Extrém } \\
\text { megriadási } \\
\text { reakció. }\end{array}$ \\
\hline
\end{tabular}


Öndestruktív illetve féktelen magatartási mintázatok egészíthetik ki a fokozott reaktivitást.

Fontos hangsúlyozni, amennyiben disszociatív tünetek is állnak a klinikai kép elôterében. Stresszor hatására ez az állapot deperszonalizáció és derealizáció formájában valósulhat meg. A deperszonalizáció a saját testtől és mentális folyamatoktól való elidegenedés élményét jelenti: a realitástól eltérô érzések önmagával és az idő múlásával kapcsolatban, az illető úgy érzi, ,mintha álmodna”. A derealizációs élmény a környezetre vonatkoztatható irrealisztikus, torzult vagy távoli megélés.

Mindkét pszichés zavarnál feltétel, hogy az érintett számára szenvedést és funkcióromlást okoz az élet valamely fontos területén, illetve nem szerhatás vagy egyéb egészségi állapot élettani hatásának következménye (DSM-5, 2013).

A traumával összefüggő mentális zavarok bemutatott két típusa felnőttekre, serdülőkre és hat évnél idősebb gyermekekre vonatkoztatható. A DSM-5 külön tárgyalja a hat évesnél fiatalabb gyermekekre érvényes diagnosztikus kritériumokat, ezek bemutatására azonban jelen tanulmány nem terjed ki.

\section{Prevalencia a tűzoltó populációban}

A traumákat követő mentális zavarok prevalenciája az átlagpopulációban több szakember érdeklődését is felkeltette, így több tanulmány is közöl erre vonatkozó adatokat. Annak ellenére, hogy a legtöbb érintett az esemény előtti funkcionálás szintjére képes visszatérni, megközelítóleg 13-22\%-uk krónikus vagy súlyos pszichés tünetegyüttest tapasztal meg (Norris,
Tracy és Galea, 2009; Tang, Lu és Xu, 2018). A beavatkozó tűzoltó állománynál magasabb arányú előfordulási gyakorisággal találkoztak egyes vizsgálatok, ami elsősorban a depresszió (Fullerton, Ursano és Wang, 2004; Stanley és tsai., 2017), szerhasználati zavarok (Bacharach, Bamberger és Doveh, 2008), valamint a poszttraumatikus stressz tünetek (Prati, Pietrantoni és Cicogani, 2011) incidenciáját jelenti.

A PTSD kapcsán a mentőalakulatok (rendőrök, tűzoltók, a mentőszolgálat munkatársai és az egészségügyi szolgáltatók) esetében világszerte 10\% körüli prevalenciát tapasztalnak a szakemberek, ez azonban a különböző szakmacsoportokon belül eltérést mutat, és akár $20 \%$ is lehet, de előfordul, hogy a 10\%-ot sem éri el (Berger és tsai., 2012). Dél-koreai mintán végzett vizsgálat viszonylag alacsonyabb előfordulási arányt mutatott ki tűzoltók körében a PTSD prevalenciájában (Kim és tsai., 2018). Ez a tendencia az átlagpopuláció tekintetében is megfigyelhető, hiszen a PTSD ritkábban van jelen az ázsiai, mint más országokban (Michael, Zetsche és Margarf, 2007).

A világban történt jelentősebb traumatikus események kapcsán egyre többször rendelkezésre állnak adatok a túlélők és a beavatkozó állomány PTSD prevalenciájával kapcsolatban. Az 1995-ös oklahomai bombázást követően a túlélők 34\%-a, valamint a beavatkozó tűzoltók 13\%-a kapta meg a diagnózist (Chemtob és tsai., 1994). A World Trade Center ikertornyainak támadása után a PTSD-vel érintett tűzoltók számát 12-17\% közöttire becsülték (Perrin és tsai., 2007). Más vizsgálatok a tűzoltó populációban 6,5\% (Haslam és Mallon, 2003) és 37\% (Bryant és Harvey, 1995) közötti intervallumot mértek a PTSD prevalencia arányában, ami nagy szórást mu- 
tat, melynek oka többek között a mintaelemszámok és a mérőeszközök eltérése.

\section{Rizikó- és protektív faktorok a PTSD kialakulásában}

A hivatásos tűzoltóknak számtalan életveszélyes káreseménynél kell helyt állniuk (Neria, Nandi és Galea, 2008). Bizonyos körülmények és ingerek azonban megnövelik annak kockázatát, hogy a megtapasztalt pszichés stressz megterhelővé, illetve elviselhetetlenné váljon, és (akár átmeneti, akár krónikus) mentális zavar alakuljon ki.

A tűzoltók számára minden kárhelyszín és káresemény más és más kihívásokat tartogat. Bármennyire is tapasztalt és felkészült egy szakember, minden bizonnyal szembesülnie kell olyan tényezőkkel a munkavégzés során, ami viszonylag váratlan. Természetesen a szolgálatteljesítés során nagy hangsúly helyeződik a felkészülésre, a katasztrófa- és egyéb tűzoltói beavatkozást igénylő szituációkat szimuláló gyakorlatok megszervezésére. A kutatók által azonban még vitatott kérdés, hogy a nagyobb szakmai tapasztalat, az ismétlődő traumatikus helyzetek átélése (Declercq és tsai., 2011), a felkészülés és a tréning (Thoresen és tsai., 2009), a hosszabb szolgálati idő, illetve az életkor (például: Norris és tsai., 2002) rizikó vagy protektív faktorként tartható-e számon.

Evolúciós eredetű reakció a „küzdj vagy menekülj” eldöntése, utóbbi azonban elenyésző esetben lehetôség a beavatkozó erôknél. A felkészültség hiányának objektív vagy szubjektív közvetlen észlelése - az a kogníció, hogy a kihívás meghaladja a képességeit - tehát érthetô módon megnöveli a stressz hatását egy professzionális személynél is (Mészáros, 2019).

Kifejezetten többletrizikóval számolhatunk, ha a beavatkozó állomány tagja személyes stresszforrásokkal is szembesül a hétköznapjaiban. Az interperszonális konfliktusok, az egzisztenciális veszteségek, a párkapcsolati problémák, a teljesítménykrízis, illetve a remélt előléptetés elmaradása mind további feszültségforrás lehet.

Az időszakos pszichológiai alkalmassági vizsgálatok ezeknek az alaprizikóknak a feltárásához szolgálnak segítségül. Abban az esetben, ha egy magánéleti krízis azonosítása megtörténik, a pszichológus szakember feladata eldönteni, igényel-e, és ha igen, milyen jellegű támogatást az érintett (pszichoedukció, figyelemmel kísérés, szupportív ellátás, pszichoterápia, esetleg pszichiátriai intervenció). Bizonyos körülmények és stresszorok mindenki számára önállóan illetve a közvetlen környezete segítségével is leküzdhetőek, azonban hangsúlyozandó annak tudatosítása, hogy szükség esetén elérhető professzionális pszichés ellátás.

Sajnos még mindig él a felnőtt férfiak körében az a sztereotípia, hogy az „erősebbik nem" maszkulin tagja nem szorul pszichológiai segítségre. A sebezhetetlenség illúziója azonban nem nyújt elegendő védelmet a traumatikus élményekkel szemben. A szomatikus és pszichés zavarok kialakulásában a szervi és idegrendszeri vulnerabilitás és rugalmasság szerepet játszik, ami egyrészt genetikai meghatározottság függvénye, azonban a külső faktorok típusa és intenzitása markánsan befolyásolja a stresszhatást és annak (pszicho)patológiai következményeit (Mészáros, 2019). 
A Maslow-féle szükséglethierarchia elméletét (Maslow, 1970) alapul véve egy traumatikus helyzetben gyakran a két alapvető szint (fiziológiai szükségletek; a biztonságérzés és a fizikai biztonság) deficites, tehát sérülékennyé válik az egyén, ami táptalajul szolgálhat pszichés zavarok kifejlődésének (Cohen és tsai., 2019).

A rizikótényezők között kerül említésre, ha a beavatkozó erők tagja korábban érkezik a kárhelyszínre, hosszabb ideig vesz részt a kárfelszámolásban (Jordan és tsai., 2019), illetve ha a körülmények tartósan veszélyt rejtenek magukban (Pfefferbaum és tsai., 2002).

Egy elhúzódó katasztrófahelyzetnél (például árvíz alkalmával) a családtól való hosszabb távollét, az alváshiány, az erôszakkal való fenyegetettség, valamint a kollégákkal való kommunikáció hiánya szintén növeli a kockázatát a túlzott stressz általi megterheltségnek (International Association of Fire Fighters, 2005).

A fizikai sérülés szintén növeli a pszichológiai kórképek kialakulásának veszélyét (Joy és tsai., 2000), illetve hátrányosan hat az áldozatokkal való azonosulás, illetve az érzelmi bevonódás átélése (Brooks és tsai., 2016). Az alacsony társas támogatás is rizikót jelent a depresszió és a PTSD megjelenésének tűzoltók körében (Regehr, Hill és Glancy, 2000; Regehr és tsai., 2002). A kifejezetten extrém rizikófaktorok listáját a 2. táblázat mutatja be.

A protektív tényezők között a társas támogatás prioritást élvez. A legtöbb traumatikus esemény alatt és azt követően a tûzoltók egymásnak nyújtott pszichés megsegítése a legtöbb esetben elégséges ahhoz, hogy az emocionális és kognitív továbblépés sikeresen bekövetkezzen.
2. táblázat: Extrém rizikófaktorok a tüzoltói beavatkozások során (Khan és tsai., 2018; Brooks és tsai., 2016; Berninger és tsai., 2010; Barnes, 1999 alapján)

Tűzoltó kolléga halála a beavatkozás során. Hozzátartozó vagy ismerôs a káresemény résztvevője.

Gyermek is résztvevője vagy áldozata a káresetnek.

Lehetséges mérgező anyagoknak való kitettség tudata.

Lehetséges fertőzésnek (AIDS, hepatitis, TBC, stb.) való kitettség tudata.

Életveszélyes, bizonytalan, előrejelezhetetlen tényezők, információhiány a beavatkozásnál.

Súlyosan sérült áldozatok, (élettel össze nem egyeztethető) holttestek.

A vezetői gondoskodás, az elöljárók elérhetősége és a kiegyensúlyozott kollegiális, illetve vezető-beosztott kapcsolat a pszichológiai jóllét alapfeltételei (Brooks és tsai., 2016). A beavatkozásokkal összefüggő tapasztalat, a felkészültség, a magasabb szakmai képzettség a PTSD és egyéb pszichés zavarok incidenciáját csökkenteni képes (Mészáros, 2019).

Hangsúlyozandó a világosan megfogalmazott, egyértelmű irányelveket felsorakoztató szakmai protokollok kidolgozása, alkalmazása (Mitchell, 2011), ami szintén képes csökkenteni a beavatkozás során éles döntési helyzetbe került tűzoltók esetleges bizonytalanságát az elöljárói elvásárokkal kapcsolatosan. A szolgálatparancsnokok előzetesen terveket készíthetnek a beavatkozó erők önellátásának megvalósításáról a kárhelyszínen, ami magában foglalja a szünetek beiktatását, a kielégítő alvást (amennyiben elhúzódó káreseményről van szó), a tápláló ételek fogyasztását, valamint a mentőmunka közbeni fizikai gyakor- 
latot (Quevillon és tsai., 2016). Ezek képezik a szervezeti-szakmai protektív feltételeket, a vezetői gondoskodás hatáskörébe tartozó intézkedéseket.

Az egyéni védettség biztosítása már a felvételkor esedékes pszichológiai szûrôvizsgálatok elvégzésénél megkezdődik. Az alkalmassági elbírálás a tűzoltó pályára készülők számára is biztonságot jelenthet, hiszen azon képességek, személyiségvonások feltérképezése történik, amelyek a jövendő helytállás prediktorai. Alapvetően a normál stresszreakcióval jellemezhetô tűzoltó-jelöltek beválogatása kívánatos, ami azt jelenti, hogy képes megfontolt, mérsékelt intenzitású, a realitáshoz illeszkedő, racionális viselkedéses válaszra (Kovács, 2019). Az elkerülő mechanizmus egy traumával való megküzdés során növeli a mentális zavarok kialakulásának kockázatát (Coffey és tsai., 1996), ezért célszerū a valódi megküzdés, a traumatikus élmények feldolgozásának facilitálása. Az alkalmazkodási készség (Masten, 2001) a túlélést és a pszichés immunrendszer optimális működését is támogatja. A humor, a pozitív gondolkodás, a problémafókuszú megküzdési stratégiák alkalmazása, illetve a traumahelyzetben az érzelmi bevonódás kerülése szintén az önvédelem része (Crowe és tsai., 2017). A magánéleti rendezettség, a partner szupportív hozzáállása is képes növelni a pszichés védelmet.

A rizikó és protektív faktorok számon tartása segítségül szolgálhat abban, hogy a káreseménnyel, katasztrófahelyzettel kapcsolatosan rendelkezésre álló információk alapján az elöljárok, az alapellátó orvos és a pszichológus szakember hatékonyan hozzon döntést arra vonatkozóan, mekkora veszélye van egy esetleges pszichés zavar kialakulásának, illetve milyen intézkedések megtétele, tényezők biztosítása jelenthet a beavatkozó állomány számára védettséget a túlzott stresszhatásokkal szemben.

\section{A prevenció}

\section{és krízisintervenció lehetőségei}

Abban az esetben, ha a kialakult krízishelyzetben - ami akár a beavatkozás alatt, akár azt követően értelmezhető - az egyén megtapasztalja, hogy pszichés és fizikális adottságai nem elégségesek és segítségre lesz szüksége a külső stresszorokkal való megküzdésben, patológiás folyamatok aktiválódhatnak (Mészáros, 2019). A sebezhetőség kogníciójának stigmatizáló hatása miatt a pszichológiai segítségkérés azonban gyakran akadályba ütközik.

Fontos hangsúlyozni, hogy a rendvédelmi állomány olyan stresszorokkal találkozik, melyek mind minőségükben, mind intenzitásukban jelentősen különböznek a hétköznapi próbatételektől. Az időben történő szakemberrel való konzultáció már rövid távon is előnyös lehet a tûzoltók számára, hiszen segíthet annak eldöntésében, mennyiben tekinthető normál reakciónak a megtapasztalt pszichés átélés, illetve a korai intervenció egy potenciálisan krónikus pszichés zavar kialakulását előzheti meg.

Az emocionális felkészülés is része a tűzoltók tréningjeinek, azonban a még meg nem tapasztalt pszichés stressz humán működésre gyakorolt hatása nem mindig előrejelezhető. Előzetesen senki sem tudhatja biztosan, milyen reakciót fog adni egy specifikus stresszhelyzetben (Regel és Joseph, 2010). A tapasztalatokkal azonban ismereteket szerezhet önmagáról, milyen erősségei és gyengepontjai vannak, és utóbbiak fejlesztésére erőfeszí- 
téseket tehet. Ezt egészítik ki a pszichológiai vizsgálatok, illetve a mentális egészség témájú tréningeken való részvétel, ezek visszajelzései, melyek alapul szolgálhatnak az önreflexiós készség javulásának, az önfejlesztésnek. A prevenció fontos része az újonc tűzoltók pszichoedukáció keretében történő felkészítése a mentális zavarok, különösképpen a PTSD szimptomatológiájának felismerésére akár saját, akár bajtársaik pszichés státuszában.

Az asszertív kommunikáció a kárhelyszínen érzett kontrollt erôsítheti azáltal, hogy a túlélők (vagy a beavatkozást végző munkatársak) intenzív emocionális reakcióinak adekvát kezelését teszi lehetővé. Az önérvényesítés a higgadt, határozott, nyilt és célirányos kapcsolatfelvételt indukálja. Az észlelt kontroll minél több területen való megvalósulása protektív faktor a krízisintervenció során. Egy katasztrófa- vagy egyéb traumahelyzet során az egyén megtapasztalja a világ és az események, de akár a saját emocionális, kognitív és viselkedéses működése fölötti befolyás elvesztését, melynek fokozatos visszaállítása szükséges.

Az adekvát preventív felkészítést követően előfordulhat, hogy egy beavatkozás után a krízisállapot oldására szükséges lépéseket tenni, a kiegyensúlyozott pszichés státusz javítása érdekében. Ezt nevezzük krízisintervenciónak (Hajduska, 2008). Sürgősségi ellátásról van szó ilyen esetben, amit az egyén emocionális-indulati labilitása, beszűkült vagy destruktív állapota tesz indokolttá. Az érintett kiszolgáltatottság-élménye által nyitott a segítségre, kifejezetten szuggerábilis, motivációja erôs. A raportépítés (stabil érzelmi kapcsolatfelvétel), a realitáskontroll megtartása, a konfliktusmegoldó technikák korrekciója, az intrapszichés élmények kifejezése, kibeszélése elsődleges cél. Az impulzivitás redukálása és a destruktív (akár öndestruktív) cselekedetek megakadályozása, a több szempontot figyelembe vevő gondolkodási mintázat elősegítése szintén vitális feladat. Az egyént hozzá kell segíteni ahhoz, hogy fenntartsa reális önértékelését, a reményt, és kontrollélményt („Bizonyos tényezők fölött van befolyásom.”). Fontos elkerülni a személy dependenciájának kialakítását (Hajduska, 2008), ehelyett az énhatékonyság támogatása javasolt.

Megfelelő motiváció és nem extrém mértékű veszteség esetén a krízisintervenció 4-5 találkozást tartalmaz a segítő szakemberrel, melynek előterében a traumatikus esemény és egyéb részletek, az érzelmi-hangulati állapot helyreállítása, a megküzdési stratégiák facilitálása, illetve a beszúkült tudatállapot oldása áll (Marmor, 1992). Amennyiben a krízisszituáció mérséklődött, a lezárás tartalmazza a további segítségnyújtás megfontolását (tanácsadás, pszichoterápia, pszichiátriai intervenció).

A poszttraumatikus stressz zavar kognitív modellje szerint megjelenése azon az élményen alapul, hogy a trauma időben és térben nem megfelelően behatárolt eseményként manifesztálódik kognitív szinten, hanem aktuális és jelen lévő fenyegetésként kerül megélésre (Ehlers és Clark, 2000). Az intervenció ennek értelmében a kritikus élmény integrációja az egyén élettörténetébe, emocionális feldolgozás révén. A támogató szociális kapcsolatok segítségével ingerexpozíció keretében (a trauma ismételt megbeszélése, már a kritikus részletekkel is kiegészítve), illetve a diszfunkcionális attitűdök (például: „Az én hibámból történt.”; „Nem szabad a tragédiára gondol- 
nom.") átstrukturálása által (Perczel Forintos, 2016). A PTSD kognitív viselkedésterápiája hatékony kezelési technika a tudományos bizonyítékok alapján, ezért indokolt esetben célszerű alkalmazásának megfontolása.

A pszichológiai intervenciók alkalmazása nemcsak a későbbi beavatkozások rendezettségének és hatékonyságának növelésére szolgál, hanem a kiegyensúlyozott életvezetés megőrzése, helyreállítása is céljuk (Mészáros, 2019).

\section{Összegzés}

A tanulmány elsődleges célja volt a rendvédelmi állomány tagjainak pszichológiai ellátásformákra történő szocializációjának elősegítése - különösképpen a tűzoltó populáció körében (tekintve, hogy a tűzoltók számos abnormális helyzetben a kárfelszámolás elsődleges szereplői).

Azon sztereotípiák, melyek szerint a pszichés segítségkérés a gyengeség jele, károsak, feloldásuk a következő évek feladata továbbra is. Egy akut vagy krónikus pszichés zavar akkora terhet képes róni az egyénre, a környezetére és a szervezeti, illetve egészségügyi rendszerre, hogy mindenképpen érdemes időt és energiát szánni a prevenció és intervenció gondos megtervezésére és alkalmazására.

\section{Irodalom}

Bacharach, S.B., Bamberger, P.A., \& Doveh, E. (2008). Firefighters, critical incidents, and drinking to cope: The adequacy of unit-level performance resources as a source of vulnerability and protection. Journal of Applied Psychology, 93(1), 155-169. doi: http://dx.doi.org/10.1037/00219010.93.1.155

Barnes, P. (1999). The experience of traumatic stress among urban firefighters Australian Journal of Emergency Management, 14(4), 6064.

Berger, W., Coutinho, E.S.F., Figueira, I., Marques-Portella, C., Luz, M.P., Neylan, T.C., Marmar, C.R., \& Mendlowicz, M.V. (2012). Rescuers at Risk: A Systematic Review and Meta-Regression Analysis of the Worldwide Current Prevalence and Correlates of PTSD in Rescue Workers. Soc. Psychiatry Psychiatr. Epidemiol., 47, 10011011. doi: 10.1007/s00127-011-0408-2

Berninger, A., Webber, M.P., Cohen. H.W., Gustave, J., Lee, R., Niles, J.K., Chiu, S., Zeig-Owens, R., Soo, J., Kelly, K., \& Prezant, D.J. (2010). Trends of elevated PTSD risk in firefighters exposed to the World Trade Center disaster: 2001-2005. Public Health Reports, 125(4), 556-566. doi: http://dx.doi.org/10.1177/00333549101 2500411

BNO-10 Zsebkönyv. DSM-IV-TR meghatározásokkal. Budapest: Animula. 2004.

Brooks, S.K., Dunn, R., Amlot, R., Greenberg, N., \& Rubin, G.J. (2016). Social and occupational factors associated with psychological distress and disorder among disaster responders: A systematic review. BMC Psychology, 4(18). doi: http:/ /dx.doi.org/10.1186/s40359-0160120-9

Bryant, R.A., \& Harvey, A.G. (1995). Posttraumatic stress in volunteer firefighters: predictors of distress. J. Nerv. Ment. Dis., 183(4), 267-271. doi: 
http:/ /dx.doi.org/10.1097/00005053-

199504000-00014

Chemtob, C.M., Hamada, R.S., Roitblat, H.L., \& Muraoka, M.Y. (1994). Anger, impulsivity, and anger control in combatrelated posttraumatic stress disorder. $J$. Consult. Clin. Psychol., 62, 827-832. doi: http:/ /dx.doi.org/10.1037/0022006X.62.4.827

Coffey, P., Leitenberg, H., Henning, K., Bennett, R.T., \& Jankowski, M.K. (1996). Dating violence: The association between methods of coping and women's psychological adjustment. Violence and Victims, 11(3), 227-238. doi: http:/ /dx.doi.org/10.1891/08866708.11.3.227

Cohen, G.H., Tamrakar, S., Lowe, S., Sampson, L., Ettman, C., Kilpatrick, D., Linas, B.P., Ruggiero, K., \& Galea, S. (2019). Improved social services and the burden of post-traumatic stress disorder among economically vulnerable people after a natural disaster: a modelling study. Lancet Planet Health, 3(2), e93-101. doi: http:/ /dx.doi.org/10.1016/S25425196(19)30012-9

Crowe, A., Glass, J.S., Lancaster, M.F., Raines, J.M., \& Waggy, M.R. (2017). A content analysis of psychological resilience among first responders and the general population. SAGE Open, 7(1). doi: http:/ /dx.doi.org/10.1177/21582440176 98530

Declercq, F., Meganck, R., Deheegher, J., \& Van Hoorde, H.(2011). Frequency of and subjective response to critical incidents in the prediction of PTSD in emergency
personnel.J. Traum. Stress, 24, 133-136. doi: http://dx.doi.org/10.1002/jts.20609

DSM-5 referencia-kézikönyv a DSM-5 diagnosztikai kritériumaihoz. Oriold és Társai,

Budapest, 2013.

Ehlers, A. \& Clark, D.M. (2000). A poszttraumás stressz-betegség kognitív modellje. In: Perczel Forintos, D. (szerk.): Psychiatria Hungarica, 15(3), 249-275.

Fullerton, C.S., Ursano, R.J., \& Wang, L. (2004). Acute stress disorder, posttraumatic stress disorder, and depression in disaster or rescue workers. The American Journal of Psychiatry, 161, 13701376.

doi: http://dx.doi.org/10.1176/appi.ajp.161.8. 1370

Hajduska, M.(2008). Krízislélektan. (pp.27-33). Budapest: Eötvös Kiadó.

Haslam, C., \& Mallon, K. (2003). A preliminary investigation of post-traumatic stress symptoms among firefighters. Work Stress, 17(3), 277-285. doi: http:/ / dx.doi.org/10.1080/02678370310 001625649

International Association of Fire Fighters (2005). Reports from the Hurricane Frontlines: Katrina. Washington, DC: International Association of Fire Fighters.

Jordan, H.T., Osahan, S., Li, J, Stein, C.R., Friedman, S.M., Brackbill, R.M., Cone, J.E., Gwynn, C., Mok, H.K., \& Farfel, M.R. (2019). Persistent mental and physical health impact of exposure to the September 11, 2001 World Trade Center terrorist attacks. Environmental Health, 18(1):12. doi: 
http:/ /dx.doi.org/10.1186/s12940-0190449-7

Joy, D., Probert, R., Bisson, J.I., \& Sheperd, J.P. (2000). Posttraumatic stress reactions after injury. J. Trauma, 48(3), 490-494. doi: http:/ /dx.doi.org/10.1097/00005373200003000-00020

Khan, K., Charters, J., Grham, T.L., Nasriani, H.R., Ndlovu, S., \& Mai, J. (2018). A case study of the effects of posttraumatic stress disorder on operational fire service personnel within the Lancashire Fire and Rescue Service. Safety and Health at Work, 9, 277-289. doi: http:/ /dx.doi.org/10.1016/j.shaw.2017.1 1.002

Kim, J.E., Dager, S.R., Jeong, H.S., Ma, J., Park, S., Kim, J., Choi, Y, Lee, S.L., Kang, I., Ha, E., Cho, H.B., Lee, S., Kim, E-J., Yoon, S., \& Lyoo, I.K. (2018). Firefighters, posttraumatic stress disorder, and barriers to treatment: Results from a nationwide total population survey. PLOS ONE 13(1): e0190630. doi: 10.1371/journal.pone.0190630

Kovács, G. (2019). A katasztrófák pszichiátriai vonatkozásai. In: Major, L., Liptay, L., \& Orgován, Gy. (szerk.) (2019). A katasztrófa-készenlét, a reagálás és a beavatkozás-biztonság egészségügyi alapjai. (pp. 394-403). Budapest: Semmelweis Kiadó.

Marmor, J. (1992). Krízisintervenció és dinamikus terápia. In: Davanloo, H., \& Sifneos, P.E. (2001). Rövid dinamikus pszichoterápia. (pp. 137-141). Budapest: Animula Kiadó.

Maslow, A.H. (1970). Motivation and personality. (Rev.ed.). New York, Harper \& Row.
Masten, A. (2001). Ordinary magic: Resilience processes in development. American Psychologist, 56(3), 227-238. doi: http:/ / dx.doi.org/10.1037/0003066X.56.3.227

Mészáros, I. (2019). Speciális munka- és egészségvédelem a beavatkozó erőknél. In: Major, L., Liptay, L., \& Orgován, Gy. (szerk.) (2019). A katasztrófa-készenlét, a reagálás és a beavatkozás-biztonság egészségügyi alapjai. (pp. 101-102). Budapest: Semmelweis Kiadó.

Michael, T., Zetsche, U., Margarf, J. (2007). Epidemiology of anxiety disorders. Psychiatry, 6(4), 136-142. doi: http://dx.doi.org/10.1016/j.mppsy.2007. 01.007

Mitchell, J.T. (2011). Collateral damage in disaster workers. International Journal of Emergency Mental Health and Human Resilience, 13(2), 121-125.

National Institute of Mental Health. Mental Health and Mass Violence. EvidenceBased early Psychological Intervention for Victims/Survivors of Mass Violence. A Workshop to Reach Consensus on Best Practices. NIH Publication 2002; No.025138, Washington,D.C. Government Printing Ofce. (www.nimh.nih.gov/research/massviolen ce.pdf)

Neria, Y., Nandi, A., \& Galea, S. (2008). Posttraumatic stress disorder following disasters: a systematic review. Psychological Medicine, 38(4), 467-480. doi:

http://dx.doi.org/10.1017/S0033291707 001353 
Norris, F.H., Friedman, M.J., Watson, P.J., Byrne, C.M., Diaz, E., Kaniasty, K. (2002). 60,000 disaster victims speak: Part I. An empirical rview of the empirical literature, 1981-2001. Psychiatry, 65, 207-239. doi: http://dx.doi.org/10.1521/psyc.65.3.207. 20173

Norris, F.H., Tracy, M., \& Galea, S. (2009). Looking for resilience: understanding the longitudinal trajectories of responses to stress. Soc. Sci. Med., 68, 2190-98. doi: http:/ /dx.doi.org/10.1016/j.socscimed.2 009.03 .043

Perczel Forintos, D. (2016). Traumatikus élmények feldolgozása kognitiv módszerekkel. Előadás: Klinikai és mentálhigiéniai szakpszichológusi szakképzés. Budapest, 2016.

Perrin, M.A., DiGrande, L., Wheeler, K., Thorpe, L., Farfel, M., \& Brackbill, R. (2007). Differences in PTSD prevalence and associated risk factors among World Trade Center disaster rescue and recovery workers. Am. J. Psychiatry, 164, 1385-1394. doi:

http:/ /dx.doi.org/10.1176/appi.ajp.2007. 06101645

Pfefferbaum, B., North, C.S., Bunch, K., Wilson, T.G., Tucker, P., \& Schorr, J.K. (2002). The impact of the 1995 Oklahoma City Bombing on the partners of firefighters. Journal of Urban Health, 79(3), 364-372. doi: http://dx.doi.org/10.1093/jurban/79.3.3 64

Prati, G., Pietrantoni, L., \& Cicognani, E. (2011). Coping strategies and collective efficacy as mediators between stress appraisal and quality of life among rescue workers. International Journal of Stress Management, 18, 181-195. doi: http://dx.doi.org/10.1037/a0021298

Quevillon, R.P., Gray, B.L, Erickson, S.E., Gonzalez, E.D., \& Jacobs, G.A. (2016). Helping the helpers: Assisting staff and volunteer workers before, during, and after disaster relief operations. Journal of Clinical Psychology, 72(12), 1348-1363. doi: http://dx.doi.org/10.1002/jclp.22336

Regehr, C., Hill, J., \& Glancy, G.D. (2000). Individual predictors of traumatic reactions in firefighters. J. Nerv. Ment. Dis., 188(6), 333-339. doi: http://dx.doi.org/10.1097/00005053200006000-00003

Regehr, C., Goldberg, G., Glancy, G.D., \& Knott, T. (2002). Posttraumatic symptoms and disability in paramedics. Can. J. Psychiatry, 47(10), 953-958. doi: http://dx.doi.org/10.1177/07067437020 4701007

Regel, S., \& Joseph, S. (2010). Post-traumatic stress. Oxford University Press.

Sinkovics, F. (2010). Pusztító tűzvész Ököritófülpösön. Magyar Hírlap.

https://tortenelemportal.hu/2010/03/puszti to-tuzvesz-okoritofulposon/ Letöltés ideje: 2020. 05. 02.

Stanley, I.H., Boffa, J.W., Hom, M.A., Kimbrel, N.A., \& Joiner, T.E. (2017). Differences in psychiatric symptoms and barriers to mental health care between volunteer and career firefighters. Psychiatry Research, 247, 236-242. doi: http://dx.doi.org/10.1016/j.psychres.201 6.11 .037

Tang, W., Lu, Y., \& Xu, J. (2018). Posttraumatic stress disorder, anxiety and 
depression symptoms among adolescent earthquake victims: comorbidity and associated sleep-disturbing factors. Soc. Psychiatry Psychiatr. Epidemiol., 53, 1241-51. doi: http://dx.doi.org/10.1007/s00127018-1576-0
Thoresen, S., Tonnessen, A., Lindgaard, C.V., Andreassen, A.L., \& Weisaeth, L. (2009). Stressful but rewarding: Norwegian personnel mobilised for the 2004 tsunami disaster. Disasters, 33, 353-368. doi: http://dx.doi.org/10.1111/j.14677717.2008.01078.x 